\title{
A comprehensive one-dimensional numerical model for solute transport in rivers
}

\author{
Maryam Barati Moghaddam, Mehdi Mazaheri, and Jamal MohammadVali Samani \\ Department of Water Structures, Tarbiat Modares University, Tehran, Iran \\ Correspondence to: Mehdi Mazaheri (m.mazaheri@modares.ac.ir)
}

Received: 4 October 2015 - Published in Hydrol. Earth Syst. Sci. Discuss.: 17 November 2015

Revised: 25 November 2016 - Accepted: 29 November 2016 - Published: 5 January 2017

\begin{abstract}
One of the mechanisms that greatly affect the pollutant transport in rivers, especially in mountain streams, is the effect of transient storage zones. The main effect of these zones is to retain pollutants temporarily and then release them gradually. Transient storage zones indirectly influence all phenomena related to mass transport in rivers. This paper presents the TOASTS (third-order accuracy simulation of transient storage) model to simulate 1-D pollutant transport in rivers with irregular cross-sections under unsteady flow and transient storage zones. The proposed model was verified versus some analytical solutions and a 2-D hydrodynamic model. In addition, in order to demonstrate the model applicability, two hypothetical examples were designed and four sets of well-established frequently cited tracer study data were used. These cases cover different processes governing transport, cross-section types and flow regimes. The results of the TOASTS model, in comparison with two common contaminant transport models, shows better accuracy and numerical stability.
\end{abstract}

\section{Introduction}

First efforts to understand the solute transport subject led to a longitudinal dispersion theory which is often referred to as the classical advection-dispersion equation (ADE; Taylor, 1954). This equation is a parabolic partial differential equation derived from a combination of a continuity equation and Fick's first law. The one-dimensional ADE equation is as follows:

$$
\frac{\partial(A C)}{\partial t}=-\frac{\partial(Q C)}{\partial x}+\frac{\partial}{\partial x}\left(A D \frac{\partial C}{\partial x}\right)-\lambda A C+A S,
$$

where $A$ is the flow area, $C$ the solute concentration, $Q$ the volumetric flow rate, $D$ the dispersion coefficient, $\lambda$ the firstorder decay coefficient, $S$ the source term, $t$ the time and $x$ the distance. When this equation is used to simulate the transport in prismatic channels and rivers with relatively uniform cross-sections, accurate results can be expected; but field studies, particularly in mountain pool-and-riffle streams, indicate that observed concentration-time curves have a lower peak concentration and longer tails than the ADE equation predictions (Godfrey and Frederick, 1970; Nordin and Sabol, 1974; Nordin and Troutman, 1980; Day, 1975). Thus a group of researchers, based on field studies, stated that to accomplish more accurate simulations of solute transport in natural rivers and streams, the ADE equation should be modified. They added some extra terms to it for consideration of the impact of stagnant areas that were so-called storage zones (Bencala et al., 1990; Bencala and Walters, 1983; Jackman et al., 1984; Runkel, 1998; Czernuszenko and Rowinski, 1997; Singh, 2003). Transient storage zones mainly include eddies, stream poolside areas, stream gravel bed, streambed sediments, porous media of river bed and banks and stagnant areas behind flow obstructions such as big boulders, stream side vegetation, woody debris and so on (Jackson et al., 2013).

In general, these areas affect pollutant transport in two ways: on the one hand, temporary retention and gradual release of solute cause an asymmetric shape in the observed concentration-time curves, which could not be explained by the classical advection-dispersion theory; on the other hand, it is also affected by the opportunity for reactive pollutants to be frequently contacted with streambed sediments that indirectly affect solute sorption, especially in low-flow condi- 
Table 1. Comparison of the features of the three models used in this study.

\begin{tabular}{llllll}
\hline & \multicolumn{5}{c}{ Model features } \\
\cline { 2 - 6 } Model & $\begin{array}{l}\text { Limitations on } \\
\text { input parameters }\end{array}$ & $\begin{array}{l}\text { Irregular } \\
\text { cross-sections }\end{array}$ & $\begin{array}{l}\text { Unsteady } \\
\text { flow }\end{array}$ & $\begin{array}{l}\text { Transient } \\
\text { storage }\end{array}$ & $\begin{array}{l}\text { Kinetic } \\
\text { sorption }\end{array}$ \\
\hline OTIS & Yes & No & No & Yes & Yes \\
MIKE 11 & No & Yes & Yes & No & No \\
TOASTS & No & Yes & Yes & Yes & Yes \\
\hline
\end{tabular}

Table 2. Comparison of numerical methods used in the three models.

\begin{tabular}{|c|c|c|c|c|}
\hline \multirow[b]{2}{*}{ Model } & \multicolumn{4}{|c|}{ Numerical methods } \\
\hline & Discretization scheme & Order of accuracy & Stability & $\begin{array}{l}\text { Numerical } \\
\text { dispersion }\end{array}$ \\
\hline TOASTS & Centered Time-QUICK Space (CTQS) & $\begin{array}{l}\text { 2nd-order in time } \\
\text { 3rd-order in space }\end{array}$ & $\mathrm{Pe}<\frac{8}{3}$ & 0 \\
\hline OTIS & Centered Time-Centered Space (CTCS) & $\begin{array}{l}\text { 2nd-order in time } \\
\text { 2nd-order in space }\end{array}$ & $\mathrm{Pe}<2$ & 0 \\
\hline MIKE 11 & Backward Time-Centered Space (BTCS) & $\begin{array}{l}\text { 1st-order in time } \\
2 \text { nd-order in space }\end{array}$ & $\mathrm{Pe}<2$ & $\frac{U^{2} \Delta t}{2}$ \\
\hline
\end{tabular}

$* \mathrm{Pe}=\frac{U \Delta x}{D}$.

Table 3. Error indices of verification by the analytical solution for continuous boundary condition.

\begin{tabular}{lrrr|r}
\hline & \multicolumn{3}{c|}{ With storage } & $\begin{array}{c}\text { Without } \\
\text { storage }\end{array}$ \\
\cline { 2 - 5 } Index & $50 \mathrm{~m}$ & $75 \mathrm{~m}$ & $100 \mathrm{~m}$ & $100 \mathrm{~m}$ \\
\hline$R^{2}(\%)$ & 99.97 & 99.96 & 99.96 & 99.99 \\
RMSE $\left(\mathrm{mg} \mathrm{m}^{-3}\right)$ & 0.021 & 0.026 & 0.033 & 0.009 \\
MAE $\left(\mathrm{mg} \mathrm{m}^{-3}\right)$ & 0.017 & 0.023 & 0.029 & 0.006 \\
MRE $(\%)$ & 0.450 & 0.780 & 1.20 & 0.640 \\
\hline
\end{tabular}

tions (Bencala, 1983, 1984; Bencala et al., 1990; Bencala and Walters, 1983).

In the literature, several approaches have been proposed to simulate solute transport in the rivers with storage areas, that one of the most commonly used is the transient storage model (TSM). TSM has been developed to consider solute movement from the main channel to stagnant zones and vice versa. The simplest form of the TSM is the one-dimensional advection-dispersion equation with an additional term to consider transient storage (Bencala and Walters, 1983). After the introduction of the TSM, transient storage processes have been studied in a variety of small mountain streams, as well as large rivers, and it was shown that simulation results of tracer study data considering the transient storage impact have good agreement with observed data. Also, it was shown that the interaction between the main channel and storage

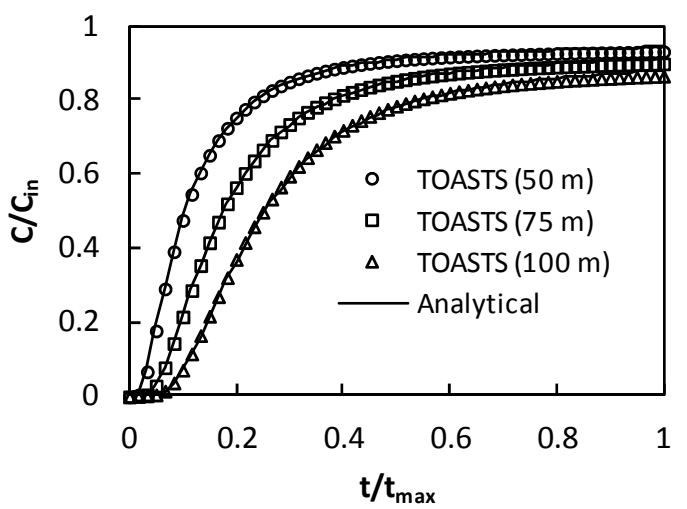

Figure 1. Results of the TOASTS model verification by the analytical solution for continuous boundary condition $(\alpha \neq 0)$.

zones, especially in mountain streams, has a great effect on solute transport behavior (D'Angelo et al., 1993; DeAngelis et al., 1995; Morrice et al., 1997; Czernuszenko et al., 1998; Chapra and Runkel, 1999; Chapra and Wilcock, 2000; Laenen and Bencala, 2001; Fernald et al., 2001; Keefe et al., 2004; Ensign and Doyle, 2005; Van Mazijk and Veling, 2005; Gooseff et al., 2007; Jin et al., 2009).

In this study, a comprehensive model, called TOASTS (third-order accuracy simulation of transient storage), able to obviate shortcomings of current models of contaminant transport, is presented. The TOASTS model uses high-order accuracy numerical schemes and considers transient storage 
Table 4. Error indices of verification by the analytical solution for Heaviside boundary condition.

\begin{tabular}{lrrr|r}
\hline & \multicolumn{3}{c|}{ With storage } & $\begin{array}{r}\text { Without } \\
\text { storage }\end{array}$ \\
\cline { 2 - 5 } Index & $50 \mathrm{~m}$ & $75 \mathrm{~m}$ & $100 \mathrm{~m}$ & $100 \mathrm{~m}$ \\
\hline$R^{2}(\%)$ & 99.98 & 99.97 & 99.96 & 99.99 \\
RMSE $\left(\mathrm{mg} \mathrm{m}^{-3}\right)$ & 0.034 & 0.045 & 0.058 & 0.0094 \\
MAE $\left(\mathrm{mg} \mathrm{m}^{-3}\right)$ & 0.031 & 0.044 & 0.056 & 0.007 \\
MRE $(\%)$ & 3.5 & 4.2 & 5 & 1.49 \\
\hline
\end{tabular}

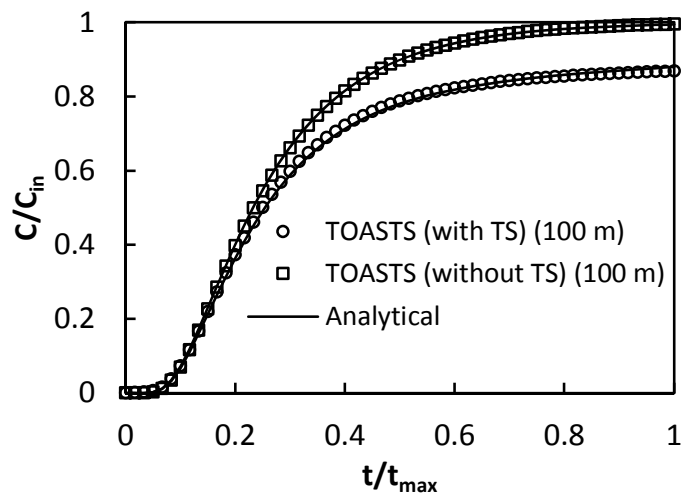

Figure 2. Results of the TOASTS model verification by the analytical solution for continuous boundary condition $(\alpha=0)$.

in rivers with irregular cross-sections under non-uniform and unsteady flow regimes. This model presents a comprehensive modeling framework that links three sub-models for calculating geometric properties of irregular cross-sections, solving unsteady flow equations and solving transport equations with transient storage and kinetic sorption.

To demonstrate the applicability and accuracy of the TOASTS model, results of two hypothetical examples (designed by the authors) and four sets of well-established tracer study data, are compared with the results of two existing frequently used solute transport models: the MIKE 11 model, developed by the Danish Hydraulic Institute (DHI), and the OTIS (one-dimensional transport with inflow and storage) model that today is the only existing model for solute transport with transient storage (Runkel, 1998). The TOASTS model and the two other model features are listed in Table 1. It should be noted that the OTIS model, in simulating solute transport in irregular cross-sections under unsteady flow regimes, has to rely on external stream routing and geometric programs. By contrast, in the TOASTS and MIKE 11 models, geometric properties and unsteady flow data are directly evaluated from river topography, bed roughness, flow initial and boundary conditions data. Another important point is in the numerical scheme which has been used in the TOASTS model solution. The key and basic difference of the TOASTS model is spatial discretization of

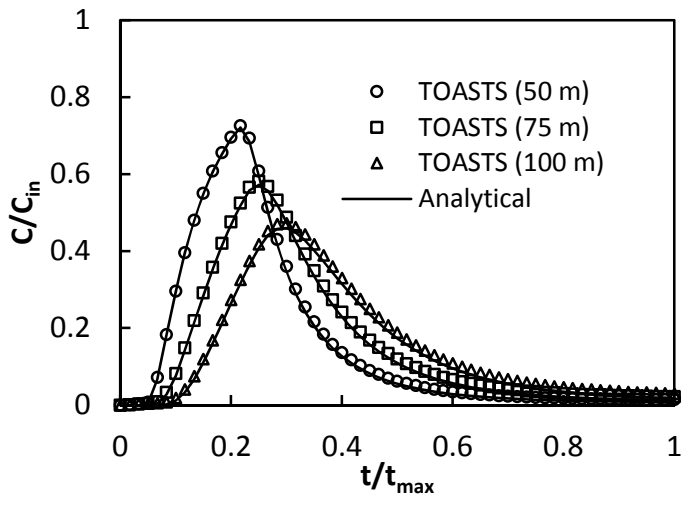

Figure 3. Results of the TOASTS model verification by the analytical solution for Heaviside boundary condition $(\alpha \neq 0)$.

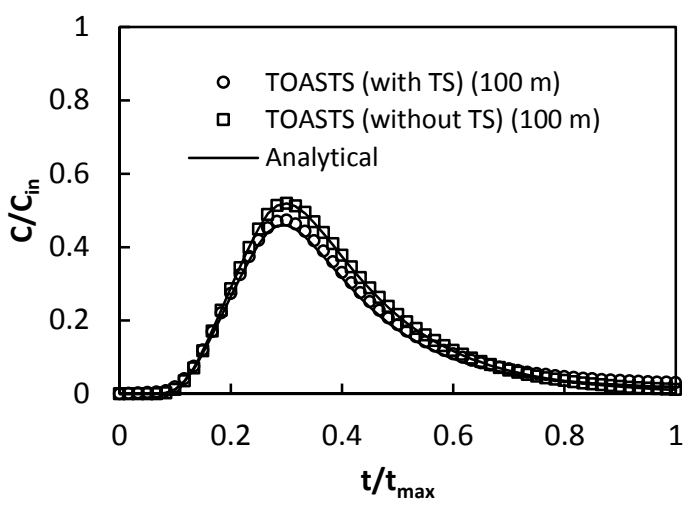

Figure 4. Results of the TOASTS model verification by the analytical solution for Heaviside boundary condition $(\alpha=0)$.

the transport equation. This model uses the control-volume approach and QUICK (quadratic upstream interpolation for convective kinematics) scheme in spatial discretization of the advection-dispersion equation considering transient storage and kinetic sorption; whereas the two other models employ central spatial differencing. More detailed comparison of numerical schemes used in the structure of three subjected models is given in Table 2.

As many researchers claim, central spatial differencing is incapable of simulation of pure advection problems and does not introduce good performance in this regard (it leads to non-convergent results with numerical oscillations; Zhang and Aral, 2004; Szymkiewicz, 2010; Versteeg and Malalasekera, 2007). It should be mentioned that, in recent years, the QUICK scheme has been widely used in numerical solutions of partial differential equations due to its high-order accuracy, very small numerical dispersion and higher stability range (Neumann et al., 2011; Lin and Medina, 2003). Hence, usage of the QUICK scheme in numerical discretization of the transport equation leads to significantly better results, especially in advection-dominant problems. 


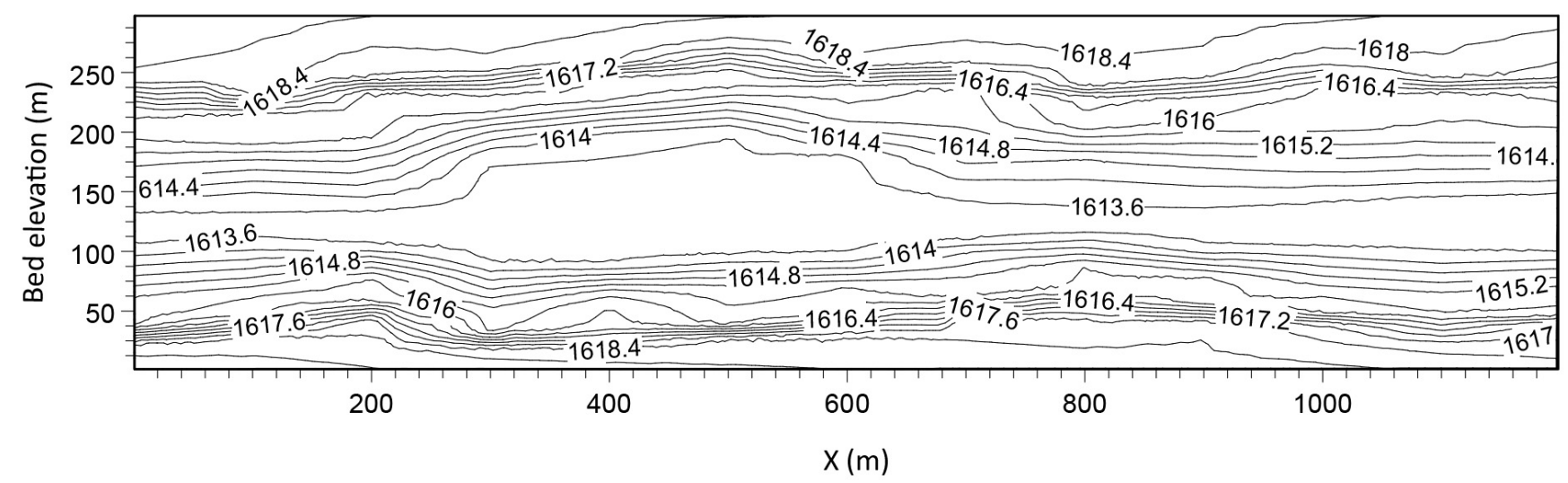

Figure 5. Bed elevation contours of the 2-D hypothetical example.

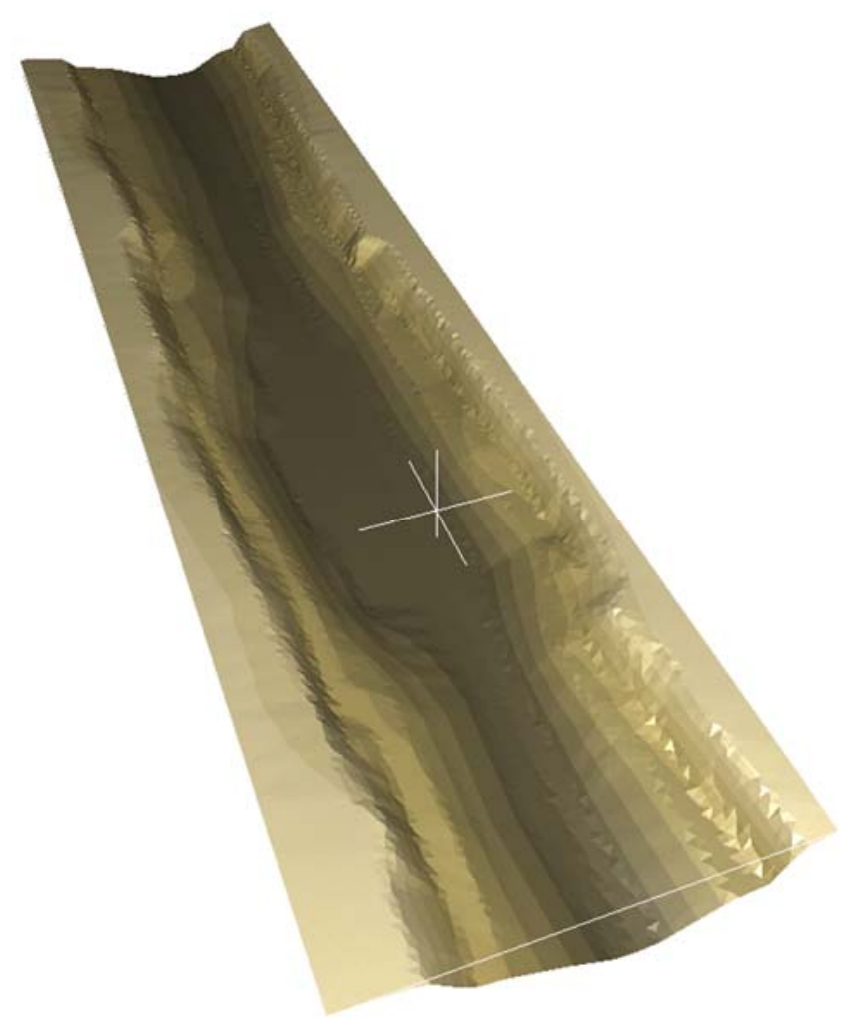

Figure 6. Bed elevation three-dimensional view of the 2-D hypothetical example.

\section{Methodology}

\subsection{Governing equations}

There are several equations for solute transport with transient storage, the most well known being the TSM presented by Bencala and Walters (1983). By writing conservation of mass principle for solute in the main channel and storage zone and
Table 5. Error indices of verification by the 2-D model.

\begin{tabular}{lrr}
\hline Index & $\begin{array}{r}\text { With } \\
\text { storage }\end{array}$ & $\begin{array}{r}\text { Without } \\
\text { storage }\end{array}$ \\
\hline$R^{2}(\%)$ & 99.97 & 99.91 \\
$\operatorname{RMSE}\left(\mathrm{mg} \mathrm{m}^{-3}\right)$ & 0.095 & 1.88 \\
$\operatorname{MAE}\left(\mathrm{mg} \mathrm{m}^{-3}\right)$ & 0.066 & 0.77 \\
$\operatorname{MRE}(\%)$ & 3.1 & 36.5 \\
\hline
\end{tabular}

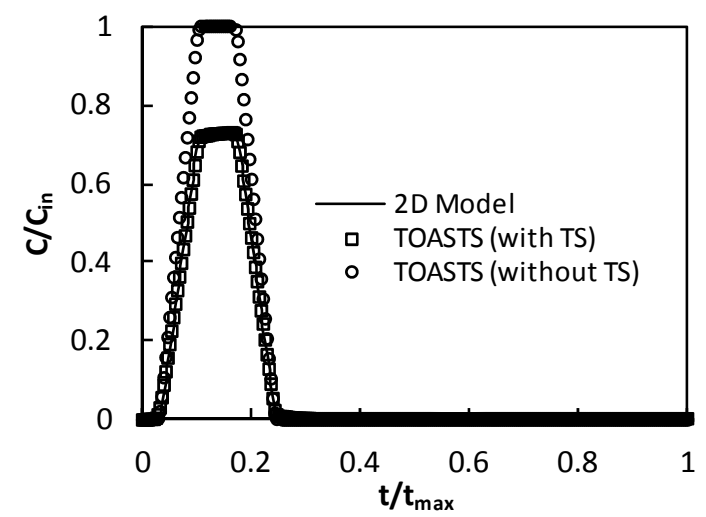

Figure 7. Results of the TOASTS model verification using the 2-D model.

doing some algebraic manipulation, a coupled set of differential equations is derived:

$$
\begin{aligned}
\frac{\partial C}{\partial t} & =-\frac{Q}{A} \frac{\partial C}{\partial x}+\frac{1}{A} \frac{\partial}{\partial x}\left(A D \frac{\partial C}{\partial x}\right) \\
& +\frac{q_{\mathrm{LIN}}}{A}\left(C_{\mathrm{L}}-C\right)+\alpha\left(C_{S}-C\right) \\
\frac{\mathrm{d} C_{\mathrm{S}}}{\mathrm{d} t} & =\alpha \frac{A}{A_{\mathrm{S}}}\left(C-C_{\mathrm{S}}\right),
\end{aligned}
$$

where $A$ and $A_{\mathrm{S}}$ are the main channel and storage zone crosssectional area respectively, $C, C_{\mathrm{L}}$ and $C_{\mathrm{S}}$ are the main chan- 
Table 6. Properties of the test cases used for the TOASTS model application.

\begin{tabular}{|c|c|c|c|c|c|c|c|c|}
\hline \multirow[b]{4}{*}{$\begin{array}{l}\text { Example } \\
\text { no. }\end{array}$} & \multirow[b]{4}{*}{$\begin{array}{l}\text { Section } \\
\text { type }\end{array}$} & \multirow[b]{4}{*}{ Flow regime } & \multicolumn{6}{|c|}{ Solute transport processes } \\
\hline & & & \multicolumn{4}{|c|}{ Physical } & \multicolumn{2}{|c|}{ Chemical } \\
\hline & & & \multirow[b]{2}{*}{ Advection } & \multirow[b]{2}{*}{ Dispersion } & \multicolumn{2}{|c|}{ Transient storage } & \multirow[b]{2}{*}{$\begin{array}{l}\text { First-order } \\
\text { decay }\end{array}$} & \multirow[b]{2}{*}{$\begin{array}{l}\text { Kinetic } \\
\text { sorption }\end{array}$} \\
\hline & & & & & Surface & $\begin{array}{l}\text { Hyporheic } \\
\text { exchange }\end{array}$ & & \\
\hline 1 & Regular & $\begin{array}{l}\text { Steady } \\
\text { Uniform }\end{array}$ & Yes & No & No & No & No & No \\
\hline 2 & Regular & $\begin{array}{l}\text { Steady } \\
\text { Uniform }\end{array}$ & Yes & Yes & No & No & Yes & No \\
\hline 3 & Irregular & $\begin{array}{l}\text { Steady } \\
\text { Non-uniform }\end{array}$ & Yes & Yes & Yes & No & No & No \\
\hline 4 & Irregular & $\begin{array}{l}\text { Steady } \\
\text { Non-uniform }\end{array}$ & Yes & Yes & Yes & No & No & Yes \\
\hline 5 & Irregular & $\begin{array}{l}\text { Steady } \\
\text { Non-uniform }\end{array}$ & Yes & Yes & Yes & No & No & No \\
\hline 6 & Irregular & $\begin{array}{l}\text { Unsteady } \\
\text { Non-uniform }\end{array}$ & Yes & Yes & No & Yes & No & No \\
\hline
\end{tabular}

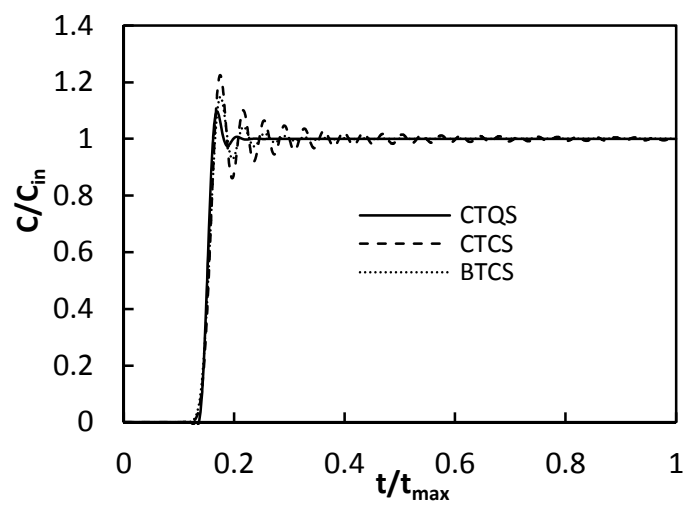

Figure 8. Comparison of the CTQS, CTCS and BTCS schemes for the pure advection test case.

Table 7. Simulation parameters related to test case 2.

\begin{tabular}{rrrrrr}
\hline$L(\mathrm{~m})$ & $\begin{array}{r}D \\
\left(\mathrm{~m}^{2} \mathrm{~s}^{-1}\right)\end{array}$ & $\begin{array}{r}\lambda \\
\left(\mathrm{s}^{-1}\right)\end{array}$ & Case & $\begin{array}{r}\text { Space } \\
\text { step }(\mathrm{m})\end{array}$ & $\begin{array}{r}\text { Peclet } \\
\text { number }\end{array}$ \\
\hline & & & 1 & 10 & 0.24 \\
2200 & 5 & 0.00002 & 2 & 100 & 2.4 \\
& & & 3 & 100 & 10 \\
\hline
\end{tabular}

nel, lateral inflow and storage zone solute concentration, respectively, $q_{\text {LIN }}$ is the lateral inflow rate and $\alpha$ is the storage zone exchange coefficient. For reactive solute, considering two types of chemical reactions (kinetic sorption and firstorder decay) Eqs. (2) and (3) are rewritten as:
Table 8. Error indices of concentration time series in test case 2.

\begin{tabular}{llrrr}
\hline & & \multicolumn{3}{c}{ Model } \\
\cline { 3 - 5 } & Index & TOASTS & OTIS & MIKE 11 \\
\hline \multirow{2}{*}{$\mathrm{Pe}=0.24$} & $R^{2}(\%)$ & 99.93 & 99.93 & 99.98 \\
& RMSE $\left(\mathrm{mg} \mathrm{m}^{-3}\right)$ & 0.460 & 0.460 & 0.850 \\
& MAE $\left(\mathrm{mg} \mathrm{m}^{-3}\right)$ & 0.236 & 0.238 & 0.480 \\
& MRE $(\%)$ & 0.9 & 1.0 & 1.7 \\
\hline $\mathrm{Pe}=2.4$ & $R^{2}(\%)$ & 98.26 & 97.82 & 97.75 \\
& RMSE $\left(\mathrm{mg} \mathrm{m}^{-3}\right)$ & 2.66 & 2.98 & 3.24 \\
& MAE $\left(\mathrm{mg} \mathrm{m}^{-3}\right)$ & 1.42 & 1.55 & 1.73 \\
& MRE $(\%)$ & 3.77 & 4.11 & 4.93 \\
\hline \multirow{2}{*}{$\mathrm{Pe}=10$} & $R^{2}(\%)$ & 98.8 & 98.2 & 98.24 \\
& RMSE $\left(\mathrm{mg} \mathrm{m}^{-3}\right)$ & 3.60 & 4.41 & 4.46 \\
& MAE $\left(\mathrm{mg} \mathrm{m}^{-3}\right)$ & 0.80 & 1.12 & 1.17 \\
& MRE $(\%)$ & 1.25 & 1.95 & 2.15 \\
\hline
\end{tabular}

$$
\begin{aligned}
\frac{\partial C}{\partial t} & =L(C)+\rho \hat{\lambda}\left(C_{\text {sed }}-K_{\mathrm{d}} C\right)-\lambda C \\
\frac{\mathrm{d} C_{\mathrm{S}}}{\mathrm{d} t} & =S\left(C_{\mathrm{S}}\right)+\hat{\lambda}_{\mathrm{S}}\left(\hat{C}_{\mathrm{S}}-C_{\mathrm{S}}\right)-\lambda_{\mathrm{S}} C_{\mathrm{S}} \\
\frac{\mathrm{d} C_{\mathrm{sed}}}{\mathrm{d} t} & =\hat{\lambda}\left(K_{\mathrm{d}} C-C_{\mathrm{sed}}\right),
\end{aligned}
$$

where $\hat{C}_{\mathrm{S}}$ is the background storage zone solute concentration, $C_{\text {sed }}$ is the sorbate concentration on the streambed sediment, $K_{\mathrm{d}}$ is the distribution coefficient, $\lambda$ and $\lambda_{\mathrm{S}}$ are the main channel and storage zone first-order decay coefficients respectively, $\hat{\lambda}$ and $\hat{\lambda}_{\mathrm{S}}$ are the main channel and storage zone sorption rate coefficients respectively, $\rho$ is the mass of acces- 

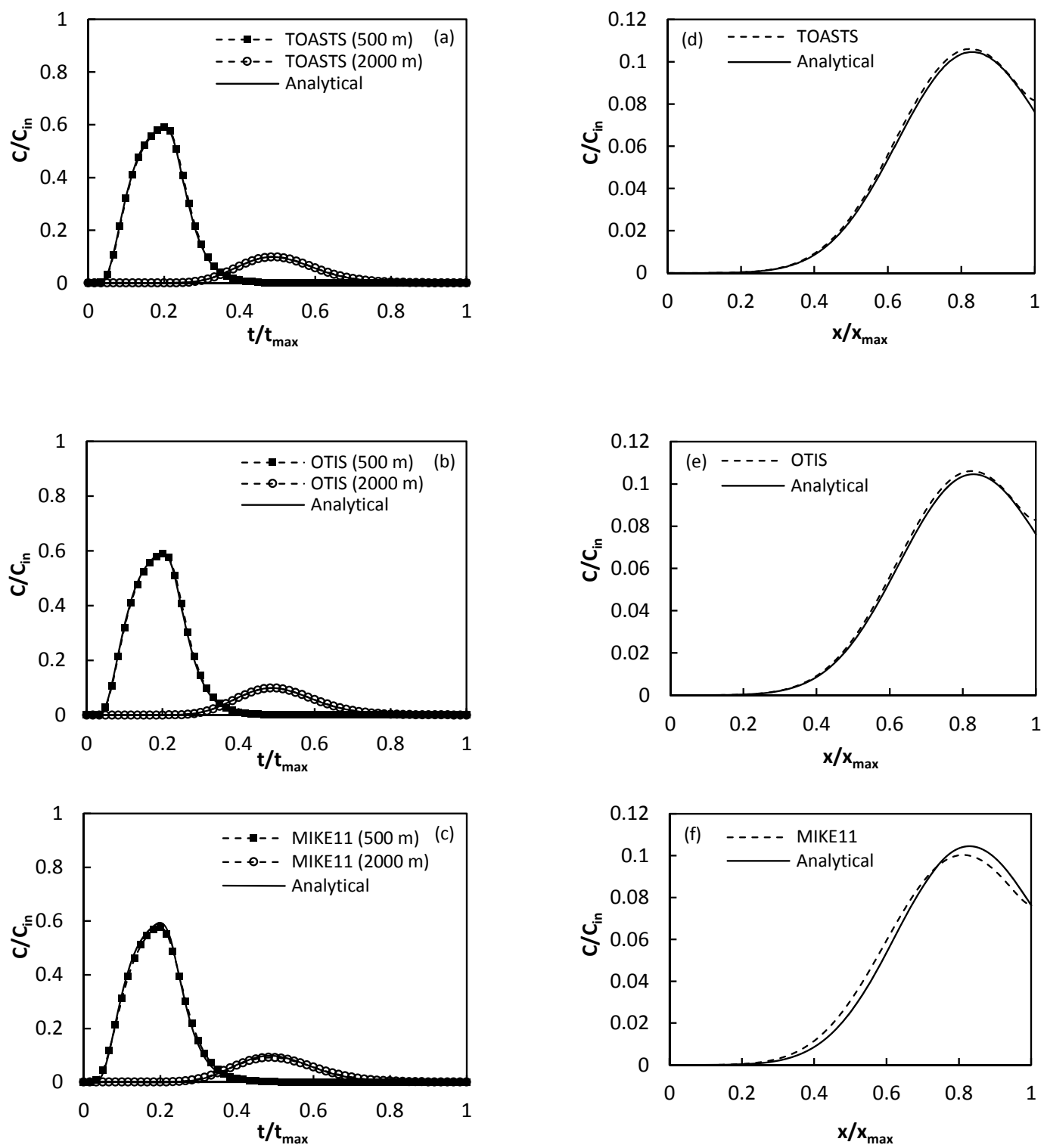

Figure 9. Comparison of the TOASTS, OTIS and MIKE 11 models in test case 2 for Pe $=0.24$.

sible sediment/volume water and $L$ and $S$ are the right-hand side differential operator of Eqs. (2) and (3) respectively.

\subsection{Numerical solution scheme}

Numerical solution of Eqs. (4) to (6) in this study are based on the control-volume method and centered time-QUICK space (CTQS) scheme. The spatial derivatives are discretized by the QUICK scheme, which is based on quadratic upstream interpolation of discretization of the advection-dispersion equation (Leonard, 1979). In this scheme, face values are computed using quadratic function passing through two upstream nodes and a downstream node. For an equally spaced grid, the values of a desired quantity, $\varphi$, on the cell faces are given by the following equations:

$$
\begin{aligned}
\phi_{\text {face }} & =\frac{6}{8} \phi_{i-1}+\frac{3}{8} \phi_{i}-\frac{1}{8} \phi_{i-2} \\
\phi_{w} & =\frac{6}{8} \phi_{W}+\frac{3}{8} \phi_{P}-\frac{1}{8} \phi_{W} W \\
\phi_{e} & =\frac{6}{8} \phi_{P}+\frac{3}{8} \phi_{E}-\frac{1}{8} \phi_{W},
\end{aligned}
$$

where $P$ denotes an unknown node with neighbor nodes $W$ (at left) and $E$ (at right). It should be noted that the corresponding cell faces are denoted by the lowercase letters, $w$ and $e$. Gradient at cell faces can be estimated using the following relationships: 

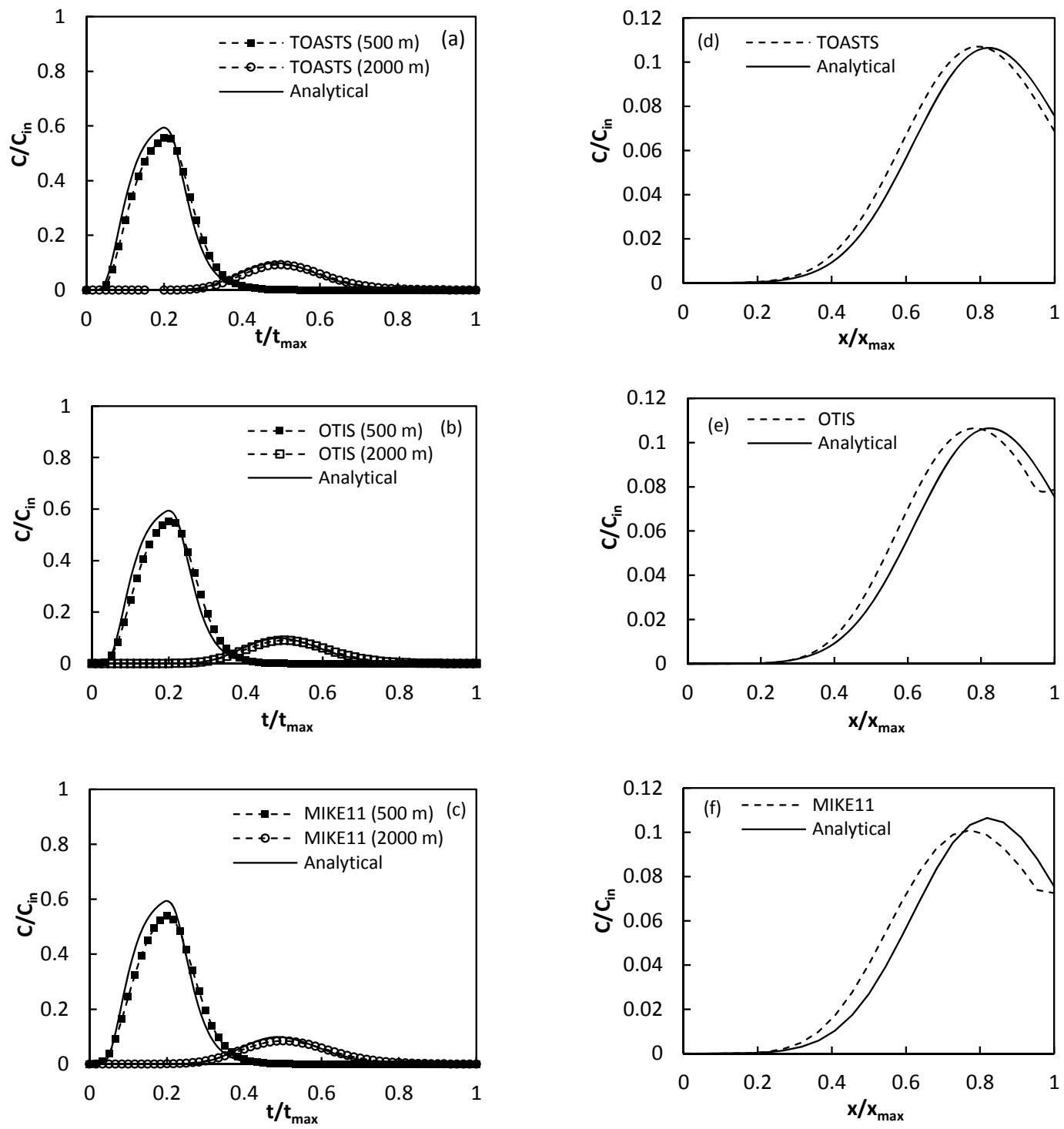

Figure 10. Comparison of the TOASTS, OTIS and MIKE 11 models in test case 2 for $\mathrm{Pe}=2.4$.

$\left(\frac{\partial \phi}{\partial x}\right)_{w}=\frac{\phi_{P}-\phi_{W}}{\Delta x}$

$\left(\frac{\partial \phi}{\partial x}\right)_{e}=\frac{\phi_{E}-\phi_{P}}{\Delta x}$.

Finally, the difference equations related to the Eqs. (4) to (6) can be derived as follows:

$$
\begin{aligned}
\frac{C_{P}^{n+1}-C_{P}^{n}}{\Delta t} & =\frac{1}{2}\left[\left(\frac{-Q_{P}}{A_{P} \Delta x}\left(C_{e}-C_{w}\right)\right)^{n+1}\right. \\
& \left.+\left(\frac{-Q_{P}}{A_{P} \Delta x}\left(C_{e}-C_{w}\right)\right)^{n}\right]
\end{aligned}
$$



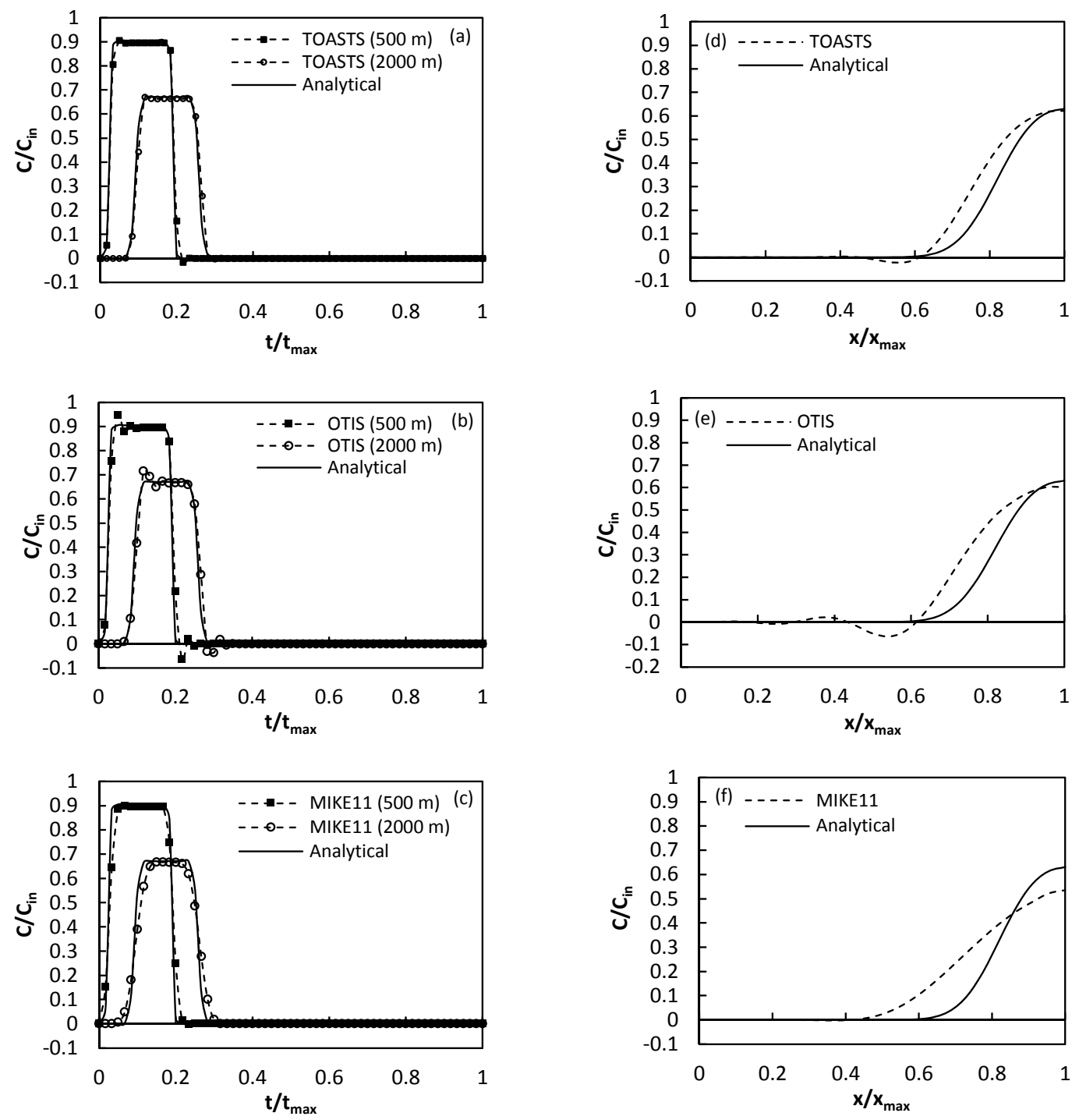

Figure 11. Comparison of the TOASTS, OTIS and MIKE 11 models in test case 2 for Pe $=10$.

$$
\begin{aligned}
\frac{C_{\mathrm{S}}^{n+1}-C_{\mathrm{S}}^{n}}{\Delta t} & =\frac{1}{2}\left[\left(\alpha \frac{A_{P}}{A_{\mathrm{S}}}\left(C_{P}-C_{\mathrm{S}}\right)\right.\right. \\
& \left.+\hat{\lambda}_{\mathrm{S}}\left(\hat{C}_{\mathrm{S}}-C_{\mathrm{S}}\right)-\lambda_{\mathrm{S}} C_{\mathrm{S}}\right)^{n+1} \\
& +\left(\alpha \frac{A_{P}}{A_{\mathrm{S}}}\left(C_{P}-C_{\mathrm{S}}\right)\right. \\
& \left.\left.+\hat{\lambda}_{\mathrm{S}}\left(\hat{C}_{\mathrm{S}}-C_{\mathrm{S}}\right)-\lambda_{\mathrm{S}} C_{\mathrm{S}}\right)^{n}\right] \\
\frac{C_{\mathrm{sed}}^{n+1}-C_{\mathrm{sed}}^{n}}{\Delta t} & =\frac{1}{2}\left[\left(\hat{\lambda}\left(K_{\mathrm{d}} C_{P}-C_{\mathrm{sed}}\right)\right)^{n+1}\right. \\
& \left.+\left(\hat{\lambda}\left(K_{\mathrm{d}} C_{P}-C_{\mathrm{sed}}\right)\right)^{n}\right] .
\end{aligned}
$$

Writing Eqs. (12) to (14) for all control-volumes in the solution domain and applying the boundary conditions, a system of linear algebraic equations will be introduced:

$a_{W W} C_{W W}^{n+1}+a_{W} C_{W}^{n+1}+a_{P} C_{P}^{n+1}+a_{E} C_{E}^{n+1}=R_{P}$,

where $a_{W}, a_{W}, a_{P}, a_{E}$ and $R_{P}$ are the corresponding coefficients and the right-hand side term. Solving this system, main channel concentrations in $n+1$ time level will be computed. Having main channel concentration values, the storage zone and streambed sediment concentrations could be calculated. 
Table 9. Error indices of concentration longitudinal profiles in test case 2.

\begin{tabular}{llrrr}
\hline & & \multicolumn{3}{c}{ Model } \\
\cline { 3 - 5 } & Index & TOASTS & OTIS & MIKE 11 \\
\hline $\mathrm{Pe}=0.24$ & $R^{2}(\%)$ & 99.9 & 99.9 & 99.9 \\
& ${\text { RMSE }\left(\mathrm{mg} \mathrm{m}^{-3}\right)}$ & 0.146 & 0.154 & 0.360 \\
& MAE $\left(\mathrm{mg} \mathrm{m}^{-3}\right)$ & 0.105 & 0.108 & 0.280 \\
& MRE $(\%)$ & 1.91 & 1.97 & 3.20 \\
\hline $\mathrm{Pe}=2.4$ & $R^{2}(\%)$ & 98.6 & 98 & 96 \\
& RMSE $\left(\mathrm{mg} \mathrm{m}^{-3}\right)$ & 0.53 & 0.65 & 0.86 \\
& MAE $\left(\mathrm{mg} \mathrm{m}^{-3}\right)$ & 0.40 & 0.47 & 0.64 \\
& MRE $(\%)$ & 5.40 & 6.56 & 11.20 \\
\hline \multirow{2}{*}{$\mathrm{Pe}=10$} & $R^{2}(\%)$ & 95.7 & 92 & 88.4 \\
& RMSE $\left(\mathrm{mg} \mathrm{m}^{-3}\right)$ & 5.46 & 7.24 & 7.88 \\
& MAE $\left(\mathrm{mg} \mathrm{m}^{-3}\right)$ & 3.02 & 4.47 & 5.05 \\
& MRE $(\%)$ & 6.27 & 12.44 & 13.50 \\
\hline
\end{tabular}

\subsection{Damköhler Index}

The Damköhler number is a dimensionless number that reflects the exchange rate between the main channel and storage zones (Jin et al., 2009; Harvey and Wagner, 2000; Wagner and Harvey, 1997; Scott et al., 2003). For a stream or channel this number is defined as:

$D a I=\alpha\left(1+\frac{A}{A_{\mathrm{S}}}\right) \frac{L}{u}$,

where $L$ is the main channel length, $u$ the average flow velocity and DaI the Damköhler number. When DaI is much greater than unity (e.g., 100), the exchange rate between the main channel and storage zone is too fast and it could be assumed that these two segments are in balance. Accordingly, when DaI is much lower than unity (e.g., 0.01) the exchange rate between main channel and storage zone is very low and negligible. In other words, in such a stream where $D a I$ is very low, there is practically no significant exchange between the main channel and storage zone, and transient storage zones do not affect downstream solute transport. Therefore, for reasonable estimation of transient storage model parameters, the DaI value must be within 0.1 to 10 range (Fernald et al., 2001; Wagner and Harvey, 1997; Ramaswami et al., 2005).

\section{Model verification}

In this section the TOASTS model is verified using several test cases. These test cases include analytical solutions of constant-coefficient governing equations for two types of upstream boundary condition (continuous and Heaviside) and also by comparing the model results with the 2-D model. Complementary explanations for each case are given below.

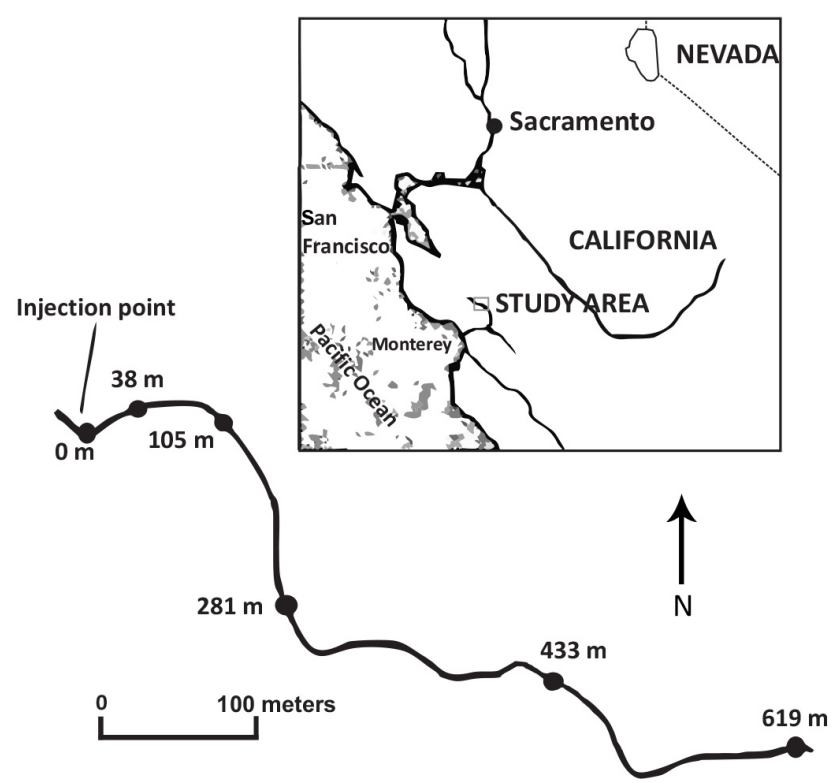

Figure 12. Uvas Creek (Santa Clara County, California) tracer study site map (Bencala and Walters, 1983).

\subsection{Verification by analytical solutions}

In this section, model verification is carried out using analytical solutions presented by Kazezyılmaz-Alhan (2008). The designed example is a $200 \mathrm{~m}$ length channel with constant cross-sectional area equal to $1 \mathrm{~m}^{2}$. The flow discharge, dispersion coefficient, storage zone area and exchange coefficient are $0.01 \mathrm{~m}^{3} \mathrm{~s}^{-1}, 0.2 \mathrm{~m}^{2} \mathrm{~s}^{-1}, 1 \mathrm{~m}^{2}$ and $0.00002 \mathrm{~s}^{-1}$, respectively. The DaI number can be calculated from the Eq. (19) equal to 0.8. This example is implemented for two different types of upstream boundary conditions: (a) continuous and (b) Heaviside.

\subsection{1 (a) Continuous boundary condition}

In this case, a solute concentration of $5 \mathrm{mg} \mathrm{m}^{-3}$ is injected continuously for $10 \mathrm{~h}$ at the inlet. The time and space steps are considered equal to $30 \mathrm{~s}$ and $1 \mathrm{~m}$, respectively. Figure 1 shows the TOASTS model results compared to the analytical solution at 50,75 and $100 \mathrm{~m}$ from the inlet. Note that both axes have been nondimensionalized with respect to the maximum values. Also, square of correlation coefficient $\left(R^{2}\right)$, root mean square error (RMSE), mean absolute error (MAE) and mean relative error (MRE) are given in Table 3. According to Fig. 1 and the error indices given in Table 3, it is clear that the trends of numerical and analytical solutions are similar, and the TOASTS model shows a good accuracy in this example.

In order to show the model capability and assess the model accuracy in a case without transient storage, the model is executed for $\alpha=0$ for this example, and the result at the distance of $100 \mathrm{~m}$ from the inlet is compared to the analytical solution 
Table 10. Simulation parameters for the Uvas Creek experiment (test case 3).

\begin{tabular}{lrrrrr}
\hline & & & \multicolumn{2}{c}{ Cross-sectional areas } & \\
Reach $(\mathrm{m})$ & $\begin{array}{r}\text { Flow } \\
\end{array}$ & $\begin{array}{r}\text { Dispersion } \\
\text { discharge }\left(\mathrm{m}^{3} \mathrm{~s}^{-1}\right)\end{array}$ & Main channel & $\begin{array}{r}\text { Storage zone } \\
\text { coefficient }\left(\mathrm{s}^{-1}\right)\end{array}$ & \\
\hline $0-38$ & 0.0125 & 0.12 & 0.30 & 0 & 0 \\
$38-105$ & 0.0125 & 0.15 & 0.42 & 0 & 0 \\
$105-281$ & 0.0133 & 0.24 & 0.36 & 0.36 & $3 \times 10^{-5}$ \\
$281-433$ & 0.0136 & 0.31 & 0.41 & 0.41 & $1 \times 10^{-5}$ \\
$433-619$ & 0.0140 & 0.40 & 0.52 & 1.56 & $4.5 \times 10^{-5}$ \\
\hline
\end{tabular}

Table 11. Error indices of simulation of the Uvas Creek experiment (test case 3).

\begin{tabular}{lrrr|rrr|rrr}
\hline & \multicolumn{3}{c}{$38 \mathrm{~m}$} & \multicolumn{3}{c|}{$281 \mathrm{~m}$} & \multicolumn{3}{|c}{$433 \mathrm{~m}$} \\
\cline { 2 - 9 } Index & TOASTS & OTIS & MIKE 11 & TOASTS & OTIS & MIKE 11 & TOASTS & OTIS & MIKE 11 \\
\hline$R^{2}(\%)$ & 94.30 & 94.20 & 94.10 & 99.40 & 99.31 & 99.10 & 98.84 & 98.8 & 97.82 \\
RMSE $\left(\mathrm{mg} \mathrm{m}^{-3}\right)$ & 0.727 & 0.728 & 0.730 & 0.180 & 0.183 & 0.340 & 0.203 & 0.205 & 0.440 \\
MAE $\left(\mathrm{mg} \mathrm{m}^{-3}\right)$ & 0.202 & 0.203 & 0.212 & 0.108 & 0.109 & 0.205 & 0.121 & 0.125 & 0.280 \\
MRE $(\%)$ & 3.50 & 3.55 & 3.68 & 2.07 & 2.08 & 3.60 & 2.27 & 2.40 & 5.30 \\
\hline
\end{tabular}

of the classical advection-dispersion equation. The results are shown in Fig. 2 and Table 3. Figure 2 also illustrates that in the case of transient storage, the concentration-time curve has a lower peak than the one without storage $(\alpha=0)$, which matches the previously mentioned transient storage concept.

\subsection{2 (b) Heaviside boundary condition}

In this case a solute concentration of $5 \mathrm{mg} \mathrm{m}^{-3}$ is injected at the inlet for a limited time of $100 \mathrm{~min}$. The time and space steps are considered equal to $30 \mathrm{~s}$ and $1 \mathrm{~m}$, respectively. Comparison of the model results and the analytical solution at the distance of 50,75 and $100 \mathrm{~m}$ from the inlet is presented in Fig. 3 and Table 4. Also, corresponding results at the distance of $100 \mathrm{~m}$ for the case without storage $(\alpha=0)$ are given in Fig. 4 and Table 4. It is obvious that the TOASTS model results in both cases (with and without storage) have a reasonable agreement with the analytical solution.

\subsection{Verification by 2-D model}

The main cause of transient storage phenomena is velocity difference between the main channel and storage zones. 2-D depth-averaged models consider velocity variations in two dimensions and give more accurate predictions of solute transport behavior in reality. Hence, they could be used for verification of the presented 1-D model as a benchmark. For this purpose, a hypothetical example was designed. To do so, a $1200 \mathrm{~m}$ long river, with irregular cross-sections, is considered. Figures 5 and 6 show bed topography of the hypothetical river. In order to take into account a hypothetical storage zone, the distance between 300 and $600 \mathrm{~m}$ of the river has been widened. The flow conditions in the river are considered to be non-uniform and unsteady. The solute concentration in the main channel and storage zone, at the beginning of the simulation (initial conditions), is assumed to be zero. In calculations of both flow and transport models, space and time steps are considered equal to $100 \mathrm{~m}$ and $1 \mathrm{~min}$ respectively. The dispersion coefficient, storage zone area and exchange coefficient are $10 \mathrm{~m}^{2} \mathrm{~s}^{-1}, 22 \mathrm{~m}^{2}$ and $1.8 \times 10^{-4} \mathrm{~s}^{-1}$, respectively. For this example the $D a I$ number is calculated equal to 0.4 . The upstream boundary condition for transport submodel is a $3 \mathrm{~h}$ lasting step loading pulse with $20 \mathrm{mg} \mathrm{m}^{-3}$ pick concentration. The results of the TOASTS model for simulating with and without transient storage were compared to the 2-D model at the distance of $800 \mathrm{~m}$ from the inlet. Figure 7 and Table 5 illustrates these results. This figure shows that with appropriate choice of $A_{\mathrm{S}}$ and $\alpha$, concentrationtime curves given by the TOASTS model are close to those given by the 2-D model. These results also imply the necessity of considering transient storage term in the advectiondispersion equation for more accurate simulation of solute transport, especially in natural rivers and streams.

\section{Application}

In this section, the applications of the TOASTS model using a variety of hypothetical examples and several sets of observed data are presented. Some properties of these test cases are given in Table 6. As shown in this table, the test cases include a wide variety of solute transport simulation applications at different conditions. 

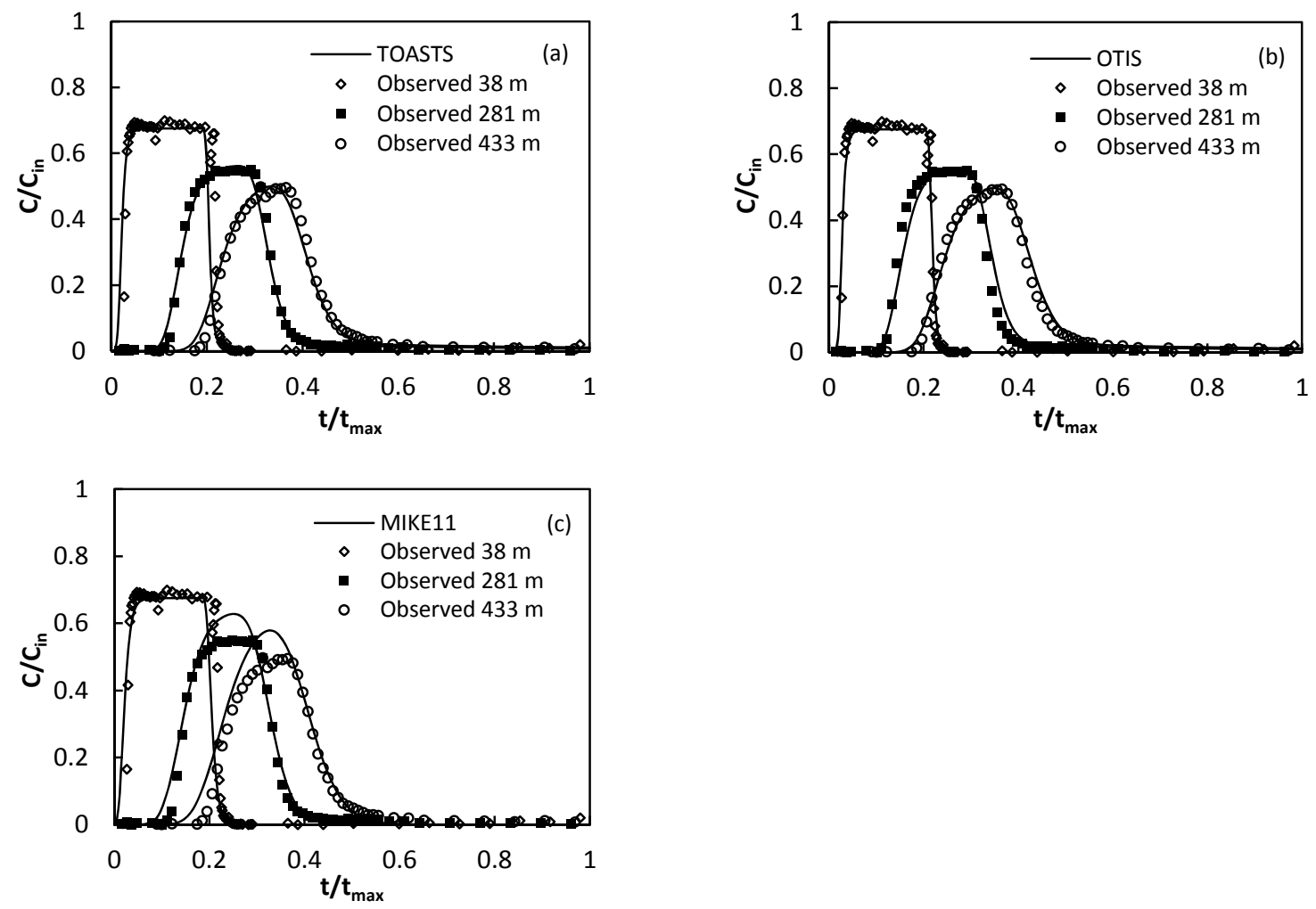

Figure 13. Observed and simulated chloride concentrations in the main channel (test case 3).

Table 12. Simulation parameters related to test case 4.

\begin{tabular}{lcr|rrr|r}
\hline & \multicolumn{2}{c}{ Sorption rate coefficient $\left(\mathrm{s}^{-1}\right)$} & \multicolumn{2}{|c}{ Background concentration $\left(\mathrm{mg} \mathrm{L}^{-1}\right)$} & \\
\cline { 2 - 5 } $\begin{array}{l}\text { Distribution } \\
\text { coefficient } \\
\left(\mathrm{m}^{2} \mathrm{~s}^{-1}\right)\end{array}$ & $\begin{array}{r}\text { Main } \\
\text { channel }\end{array}$ & $\begin{array}{r}\text { Storage } \\
\text { zone }\end{array}$ & $\begin{array}{r}\text { Main } \\
\text { channel }\end{array}$ & $\begin{array}{r}\text { Storage } \\
\text { zone }\end{array}$ & $\begin{array}{r}\text { Bed } \\
\text { sediments }\end{array}$ & $\begin{array}{r}\text { Input } \\
\text { concentration } \\
\left(\mathrm{mg} \mathrm{L}^{-1}\right)\end{array}$ \\
\hline 70 & $56 \times 10^{-6}$ & 1 & 0.13 & 0.13 & $9.1 \times 10^{-3}$ & 1.73 \\
\hline
\end{tabular}

\subsection{Test case 1: pure advection}

In order to show the advantage of the numerical scheme used in the TOASTS model, for advection-dominant problems, a hypothetical example was designed and three numerical schemes were applied: CTQS (centered time-quick space), CTCS (centered time-centered space) and BTCS(backward time-centered space). To do so, steady flow by velocity of $1 \mathrm{~m} \mathrm{~s}^{-1}$ was assumed. Total simulation time was $5 \mathrm{~h}$ and space and time steps were $100 \mathrm{~m}$ and $10 \mathrm{~s}$ respectively. Note that advection is the only transport mechanism. The results of this test case are depicted in Fig. 8. It is clear that, for the pure advection simulation, the CTQS scheme has less oscillation than the other two schemes. In particular, this figure indicates that the result of the CTCS scheme, which is used in the OTIS model, shows high oscillations. Therefore, it can be concluded that for advection-dominant sim- ulation the TOASTS model has a better performance. It is interesting to note that in mountain rivers where the transient storage mechanism is more observed, due to relatively high slope, higher flow velocities occur which lead to advectiondominant solute transport.

\subsection{Test case 2: transport with first-order decay}

This example illustrates the application of the TOASTS model in solute transport simulation by first-order decay. A decaying substance enters the stream with steady and uniform flow during a $2 \mathrm{~h}$ period. The solute concentration at the upstream boundary is $100 \mathrm{mg} \mathrm{m}^{-3}$. Also, in order to assess the TOASTS model capability in the case of high-flow velocity and advection-dominant transport, this example implemented for three cases with different Peclet numbers. The simulation parameters for different cases are given in Table 7 . 


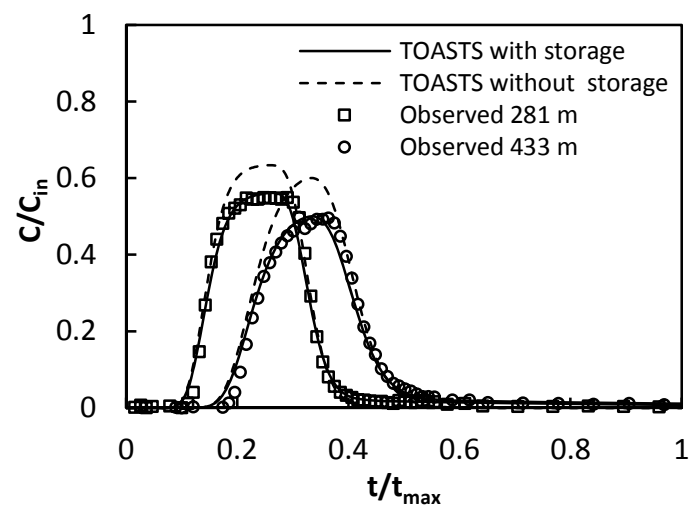

Figure 14. The TOASTS model results for simulation with and without transient storage (test case 3 ).

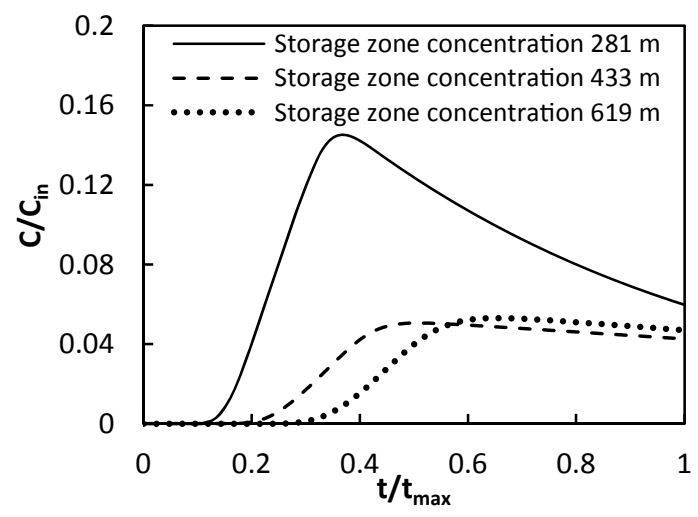

Figure 15. Observed and simulated storage zone concentrations computed by the TOASTS model (test case 3 ).

Figures 9-11 show simulation results of the three numerical models in comparison with analytical solution. Error indices are given in Tables 8 and 9. It is obvious from Fig. 9a-c that in the first case (Peclet number less than 2), all methods simulated concentration-time curves accurately. Also, Fig. 9d-f show that the MIKE 11 model cannot simulate a concentration longitudinal profile accurately, because it does not consider the transient storage effect on solute transport.

In the second case, by increasing the computational space step, all methods show a drop in the peak concentration, that its amount for the MIKE 11 model is more and for the TOASTS model is less than the others (Fig. 10a-c). Figure 10d-f and Table 9 show that the results of the models that use the central differencing scheme in spatial discretization of transport equations show more discrepancy in comparison with the analytical solution.

In the third case, flow velocity increased about four times. As illustrated in Fig. 11c, by increasing the Peclet number, the OTIS model results show more oscillations. This model also shows very intense oscillations in the longitudinal concentration profile in the form of negative concentrations
(Fig. 11e), while observed oscillations in the TOASTS model are very small compared to the OTIS model (Fig. 11d). However, the QUICK scheme oscillations in advection-dominant cases are less likely to corrupt the solution. Also the MIKE 11 model results, in comparison with the TOASTS model, have greater difference with the analytical solution.

The main reason for the difference between the obtained results in the three cases is actually related to how advection and dispersion affect the solute transport. The dispersion process affects the distribution of solute in all directions, whereas advection acts only in the flow direction. This fundamental difference manifests itself in the form of limitation in computational grid size.

\subsection{Test case 3: conservative solute transport with transient storage}

This example shows the TOASTS model application to field data, by using the conservative tracer (chloride) injection experiment results, which was conducted in Uvas Creek, a small mountain stream in California (Fig. 12). Details of the experiments can be found in Avanzino et al. (1984). Table 10 shows simulation parameters for the Uvas Creek experiment (Bencala and Walters, 1983). For assessing efficiency and accuracy of the three discussed models in simulation of the impact of physical processes on solute transport in a mountain stream, they are implemented for this set of observed data. Figure 13a-c illustrates simulated chloride concentration in the main channel. It can be seen from these figures and Table 11 that the TOASTS model simulated the experiment results slightly better than the two other models. Comparison of Fig. 13a and b shows that the TOASTS and OTIS models have good accuracy in modeling the peak concentration and the TOASTS model has a slightly better performance in simulation of a rising tail of concentration-time curve, particularly in the $281 \mathrm{~m}$ station. Figure $13 \mathrm{c}$ shows MIKE 11 model results. It shows significant discrepancies with the observed data, particularly in peak concentrations. However, at the $38 \mathrm{~m}$ station, where transient storage has not still affected solute transport, the results of the three models have little difference with the observed data (Table 11). Figure 14 depicts the TOASTS model results for the Uvas Creek experiment for simulations with and without transient storage at the 281 and $433 \mathrm{~m}$ stations. This figure shows that in simulation with transient storage, the results have more fitness with the observed data in general shape of the concentration-time curve, peak concentration and peak arrival time. Figure 15 shows the simulated chloride concentrations in the storage zone. The concentration-time curves in the storage zone have longer tails in comparison with the main channel. That means some portions of the solute mass remain in the storage zones and gradually return to the main channel. 

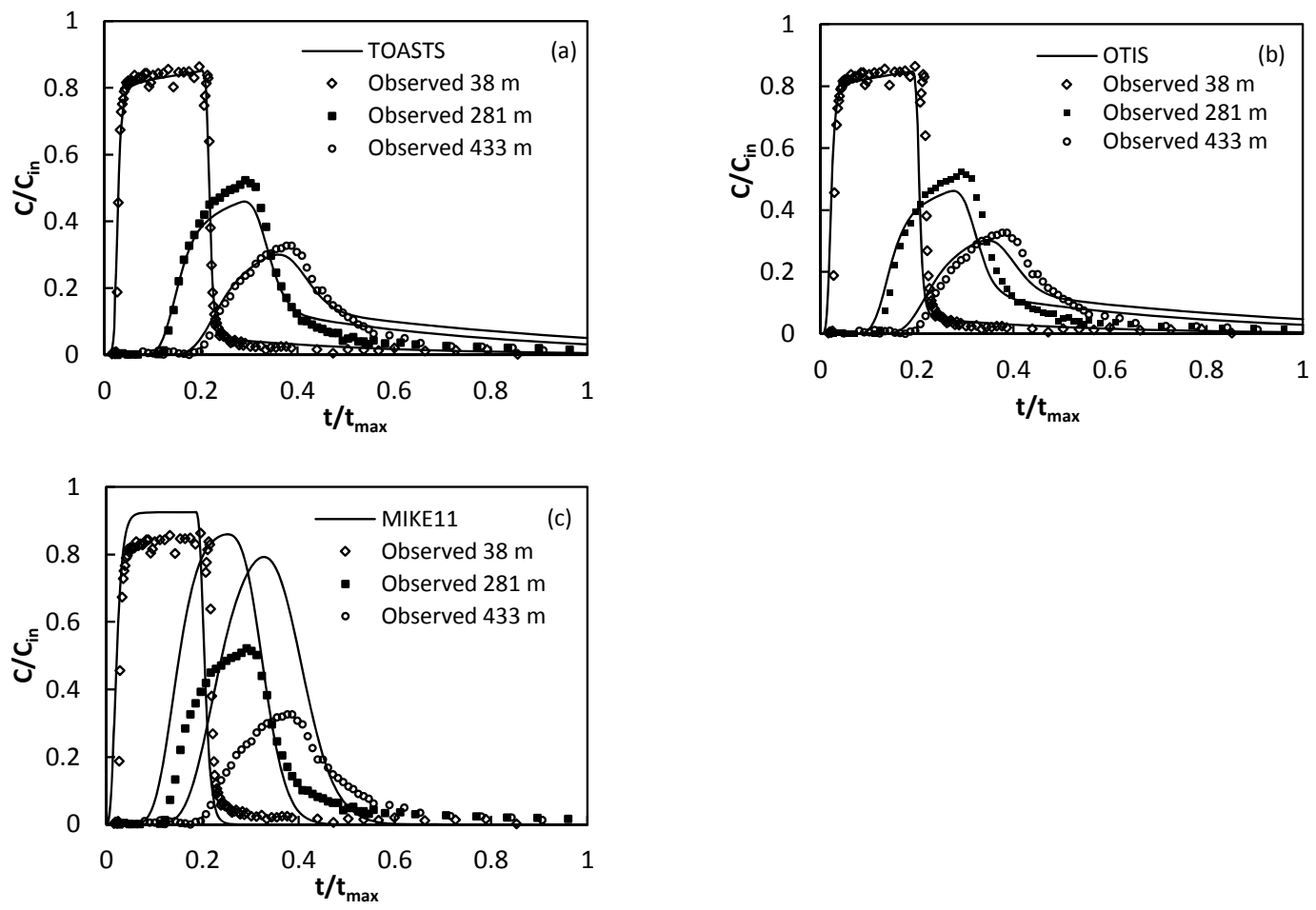

Figure 16. Observed and simulated strontium concentrations in the main channel (test case 4).
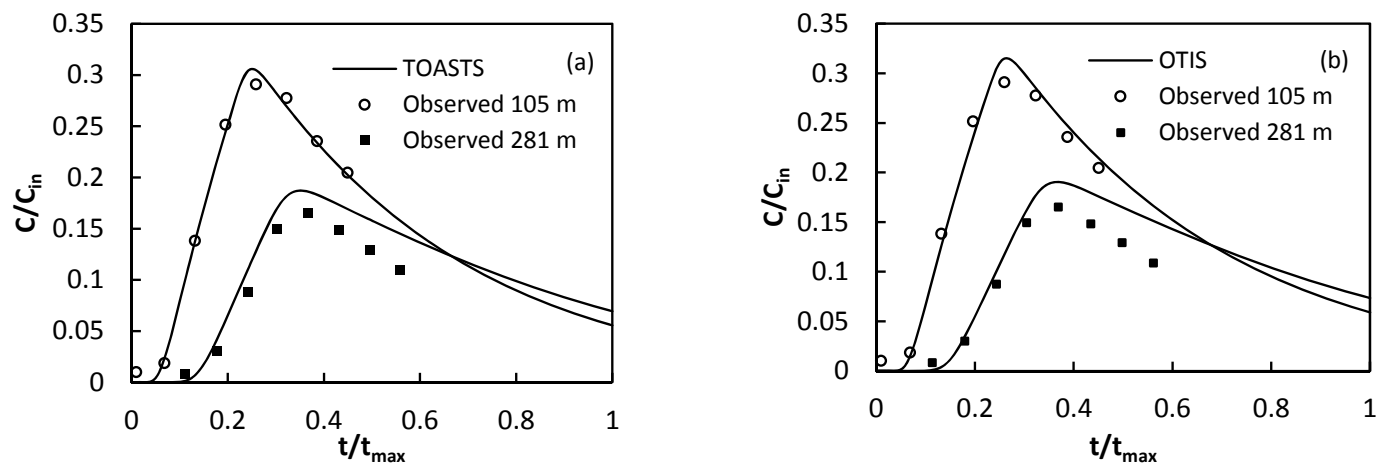

Figure 17. Observed and simulated sorbate strontium concentrations in the Uvas Creek experiment (test case 4).

\subsection{Test case 4: non-conservative solute transport with transient storage}

The objective of this test case is to demonstrate the capability of the TOASTS model in non-conservative solute transport modeling in natural rivers. For this purpose, the field experiment of the $3 \mathrm{~h}$ reactive tracer (strontium) injection into the Uvas Creek was used. The experiment was conducted at lowflow conditions and, due to the high opportunity of solute having frequent contact with relatively immobile streambed materials, solute and streambed interactions and solute sorption into bed sediments were more intense than during the high-flow conditions. Hence, the sorption process must be considered in simulation of this experiment (Bencala, 1983). Some of the simulation parameters are given in Table 12 and the other parameters are the same as those given in Table 10. Figure 16a-c and Table 13 show solute transport simulation results of the three subjected models in comparison with the observed data. According to these figures it could be said that the TOASTS model shows better fitness with the observed data. Figure 16c shows that simulation without taking into account the transient storage and kinetic sorption in the MIKE 11 model leads to very poor results. The zero exchange coefficient at the $38 \mathrm{~m}$ station causes reasonable results by this model at this station. Figure 17 illustrates the TOASTS and OTIS model results for sorbate concentrations 
Table 13. Error indices of simulation of the Uvas Creek experiment (test case 4).

\begin{tabular}{|c|c|c|c|c|c|c|c|c|c|c|}
\hline \multirow[b]{3}{*}{ Index } & \multicolumn{6}{|c|}{ Main channel concentration } & \multicolumn{4}{|c|}{ Sorbate concentration } \\
\hline & \multicolumn{3}{|c|}{$38 \mathrm{~m}$} & \multicolumn{3}{|c|}{$281 \mathrm{~m}$} & \multicolumn{2}{|c|}{$105 \mathrm{~m}$} & \multicolumn{2}{|c|}{$281 \mathrm{~m}$} \\
\hline & TOASTS & OTIS & MIKE 11 & TOASTS & OTIS & MIKE 11 & TOASTS & OTIS & TOASTS & OTIS \\
\hline$R^{2}(\%)$ & 99.30 & 93.17 & 93.00 & 99.00 & 96.00 & 90.80 & 99.40 & 99.30 & 99.16 & 98.6 \\
\hline $\operatorname{RMSE}\left(\mathrm{mg} \mathrm{m}^{-3}\right)$ & 0.05 & 0.12 & 0.17 & 0.055 & 0.070 & 0.200 & 1.05 & 1.64 & 2.67 & 2.86 \\
\hline $\operatorname{MAE}\left(\mathrm{mg} \mathrm{m}^{-3}\right)$ & 0.021 & 0.044 & 0.086 & 0.048 & 0.055 & 0.115 & 0.75 & 1.50 & 2.40 & 2.41 \\
\hline $\operatorname{MRE}(\%)$ & 6.40 & 11.80 & 24.60 & 13.60 & 18.00 & 27.40 & 3.04 & 5.66 & 10.50 & 10.80 \\
\hline
\end{tabular}

Table 14. Error indices of the Athabasca River experiment (test case 5).

\begin{tabular}{lrrr}
\hline & \multicolumn{3}{c}{ Distance from upstream, $1850 \mathrm{~m}$} \\
\cline { 2 - 4 } Index & TOASTS & OTIS & MIKE 11 \\
\hline$R^{2}(\%)$ & 99.75 & 99.8 & 62.5 \\
RMSE $\left(\mathrm{mg} \mathrm{m}^{-3}\right)$ & 0.030 & 0.047 & 0.50 \\
MAE $\left(\mathrm{mg} \mathrm{m}^{-3}\right)$ & 0.020 & 0.025 & 0.260 \\
MRE $(\%)$ & 1.70 & 4.77 & 28.60 \\
\hline
\end{tabular}

Table 15. Simulation parameters related to test case 6 .

\begin{tabular}{lrrr}
\hline $\begin{array}{l}\text { Reach } \\
(\mathrm{m})\end{array}$ & $\begin{array}{r}\text { Dispersion } \\
\text { coefficient }\left(\mathrm{m}^{2} \mathrm{~s}^{-1}\right)\end{array}$ & $\begin{array}{r}\text { Storage zone } \\
\text { area }\left(\mathrm{m}^{2}\right)\end{array}$ & $\begin{array}{r}\text { Exchange } \\
\text { coefficient }\left(\mathrm{s}^{-1}\right)\end{array}$ \\
\hline $0-213$ & 0.50 & 0.20 & $1.07 \times 10^{-3}$ \\
$213-457$ & 0.50 & 0.25 & $5.43 \times 10^{-4}$ \\
$457-726$ & 0.50 & 0.14 & $1.62 \times 10^{-2}$ \\
\hline
\end{tabular}

on the streambed sediments versus the observed data at the 105 and $281 \mathrm{~m}$ stations. It is clear from this figure and Table 13 that the TOASTS model is slightly better fitted to the observed data.

\subsection{Test case 5: solute transport with transient storage in a river with irregular cross-sections}

This test case shows the TOASTS model application for a river with irregular cross-sections under non-uniform flow conditions. The real data set for this test case was collected in a tracer experiment which has been done in the Athabasca River near Hinton, Alberta, Canada. Details of the experiments can be found in Putz and Smith (2000). In this study, the simulation reach length is $8.3 \mathrm{~km}$, between 4.725 to $13.025 \mathrm{~km}$ of the river. The main reason for selecting this reach is that it has common geometric properties of rivers with storage zones. Total simulation time is $10 \mathrm{~h}$, space and time steps are considered equal to $25 \mathrm{~m}$ and $1 \mathrm{~min}$, respectively. The exchange coefficient is assumed equal to $6 \times 10^{-4} \mathrm{~s}^{-1}$ by calibration. According to the estimated parameters, DaI is calculated equal to 3.8 which is in the acceptable range and therefore transient storage zones affect

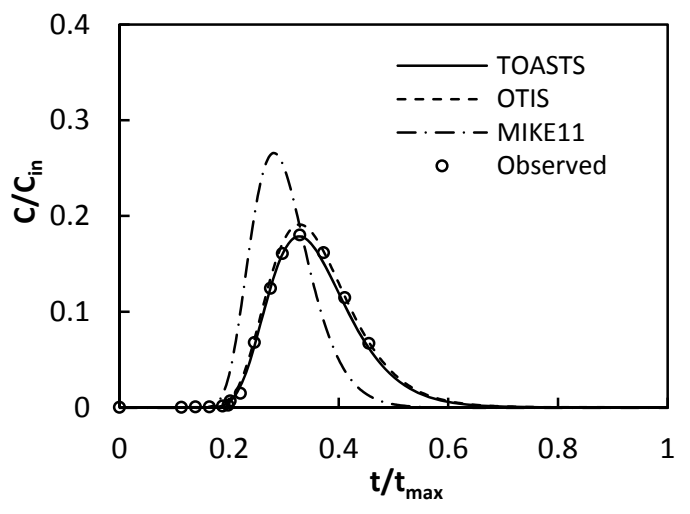

Figure 18. Simulation results for the Athabasca River experiment (test case 5).

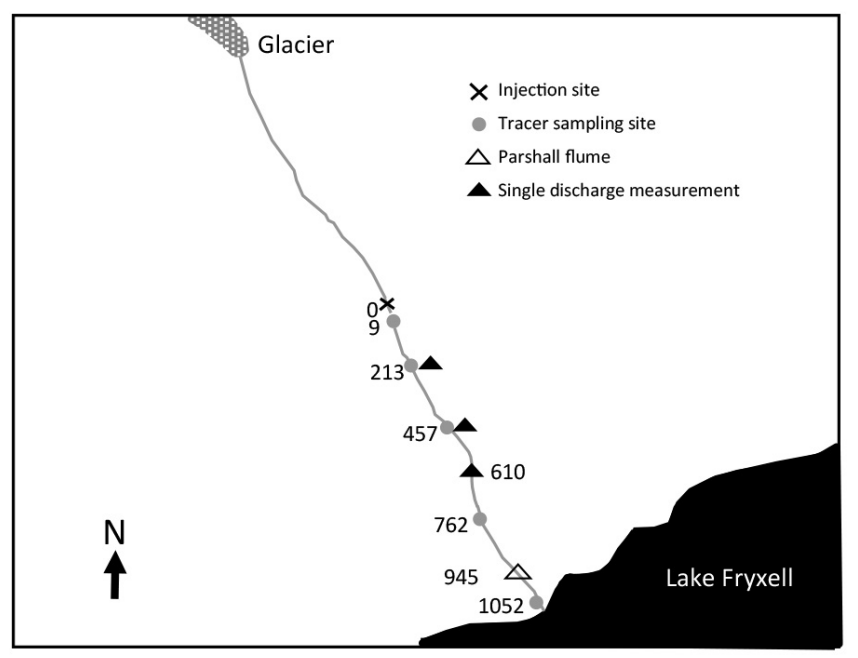

Figure 19. Huey Creek tracer study site map (Runkel et al., 1998).

downstream solute transport in the simulation reach. Since samples were collected only in four cross-sections downstream of the injection site, the observed concentration-time curve at $4.725 \mathrm{~km}$ was used as an upstream boundary condition of the transport model and the observed concentrationtime curve at $11.85 \mathrm{~km}$ was used to compare the model results with the observed data. Figure 18 and Table 14 repre- 
Table 16. Huey Creek experiment error indices (test case 6).

\begin{tabular}{lrrr|rrr}
\hline & \multicolumn{3}{c|}{$213 \mathrm{~m}$} & \multicolumn{3}{c}{$457 \mathrm{~m}$} \\
\cline { 2 - 7 } Index & TOASTS & OTIS & MIKE 11 & TOASTS & OTIS & MIKE 11 \\
\hline$R^{2}(\%)$ & 68.6 & 67 & 84 & 78 & 63.5 & 94 \\
RMSE $\left(\mathrm{mg} \mathrm{m}^{-3}\right)$ & 0.673 & 0.674 & 0.740 & 0.48 & 0.63 & 0.62 \\
MAE $\left(\mathrm{mg} \mathrm{m}^{-3}\right)$ & 0.28 & 0.30 & 0.54 & 0.23 & 0.28 & 0.52 \\
MRE $(\%)$ & 7.14 & 7.32 & 20.40 & 6.46 & 7.60 & 15 \\
\hline
\end{tabular}
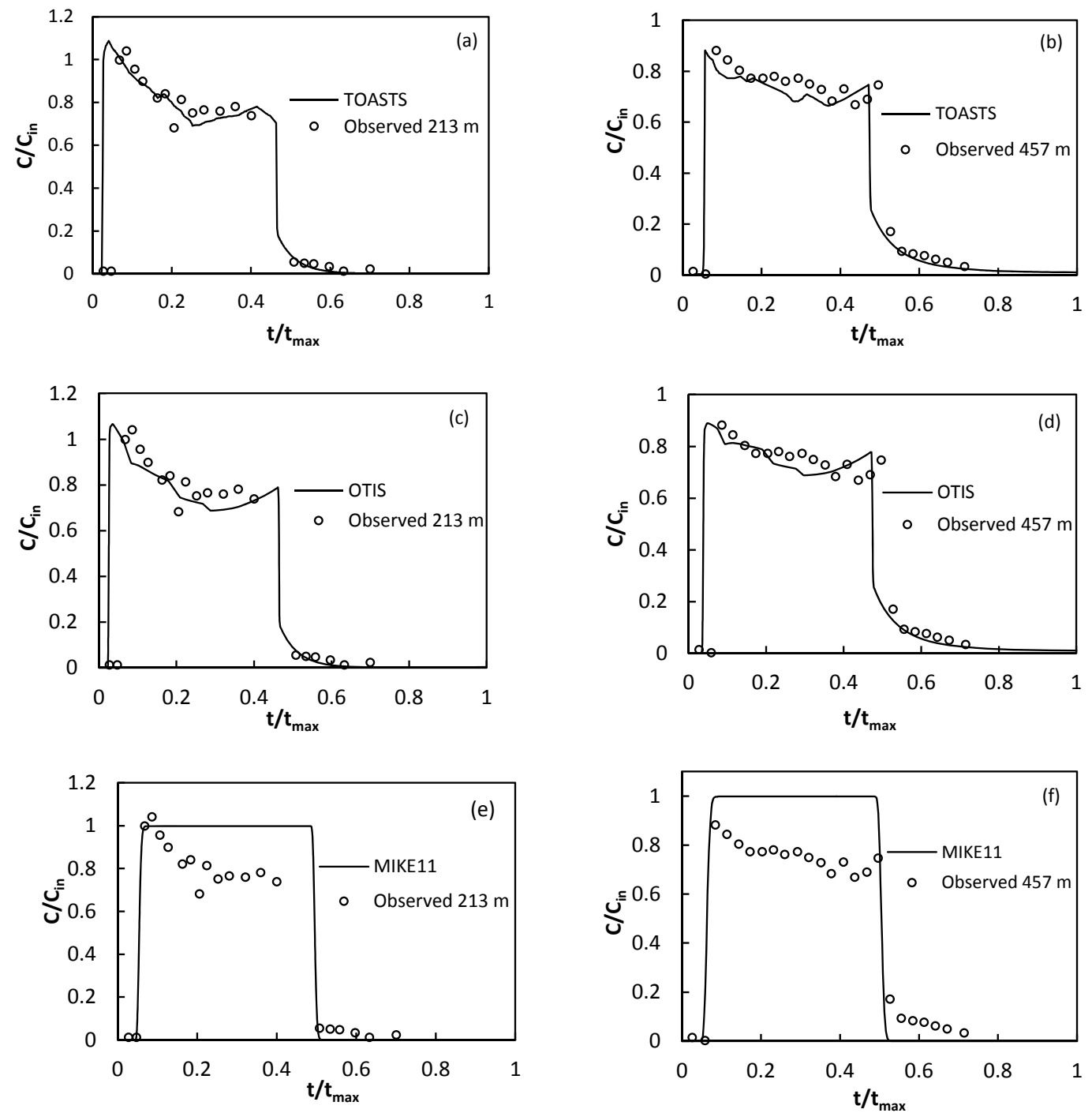

Figure 20. Observed and simulated main channel lithium concentrations (test case 6).

sent Athabasca experiment simulation results. It is clear that the concentration-time curves simulated by the TOASTS and OTIS models fit very well with the observed data; but again the MIKE 11 model failed to reproduce an accurate result, which means a poor performance of the classical advection- dispersion equation in simulation of solute transport in natural rivers. 


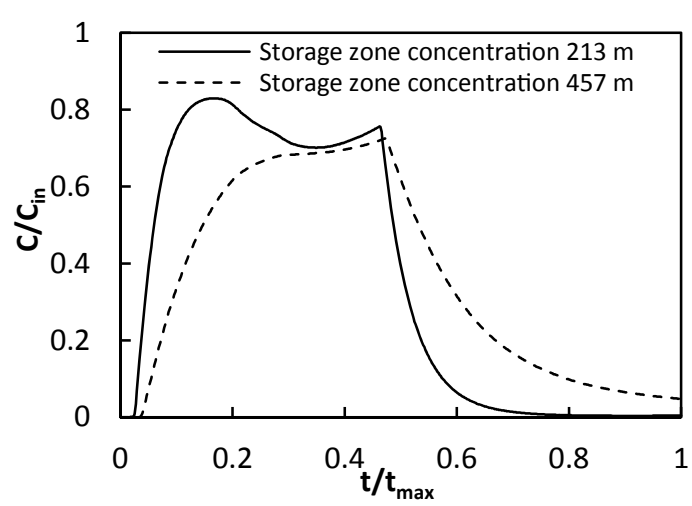

Figure 21. Simulated storage zone concentrations (test case 6).

\subsection{Test case 6: solute transport with hyporheic exchange under unsteady flow conditions}

This test case shows an application of the TOASTS model to simulate solute transport in a stream with irregular crosssections, under an unsteady flow regime. In most of solute transport models, for simplification, flow is considered to be steady, while in most natural rivers unsteady flow condition is common, and neglecting temporal flow variations may lead to inaccurate results for solute transport simulation.

Tracer study that is used in this section, conducted in January 1992 at Huey Creek, located in McMurdo valleys, Antarctica (Fig. 19). The flow rate was variable from 1 to $4 \mathrm{c} \mathrm{fs}^{-1}$ (cubic feet per second) during the experiments. Since this stream does not have obvious surface storage zones, the cross-sectional area of storage zones and exchange rate of this area actually represent the rate of hyporheic exchange and interaction between surface and subsurface water (Runkel et al., 1998). Details of the experiments can be found in Runkel et al. (1998). Table 15 shows the simulation parameters. Figure $20 \mathrm{a}-\mathrm{c}$ and Table 16 represent simulation results of lithium concentration at the 213 and $457 \mathrm{~m}$ stations, by the three subjected models. The results of the TOASTS model have a slightly better fitness to the observed data than the two other models. This figure also indicates that the general shape of the concentration-time curve for this example is a little different from the other examples. Figure 20c represents the results of the MIKE 11 model. As seen in this figure, results have large differences with the observed data in peak concentrations and general shape of the curve. Figure 21 shows the corresponding storage zone concentrations at 213 and $457 \mathrm{~m}$ stations. It can be seen that solute concentration-time curves in the storage zone have lower peaks and much longer tails, which imply longer residence time of solute in these areas compared to the main channel.

\section{Conclusions}

In this study a comprehensive model was developed that combines numerical schemes with high-order accuracy for solution of the advection-dispersion equation, considering transient storage zones term in rivers. In developing the subjected model (TOASTS), for achieving better accuracy and applicability, irregular-cross sections and an unsteady flow regime were considered. For this purpose the QUICK scheme, due to its high stability and low approximation error, has been used for spatial discretization.

The presented model was verified successfully using several analytical solutions and 2-D hydrodynamics and transport model as benchmarks. Also, its validation and applications were proved using several hypothetical examples and four sets of well-established tracer experiments data under different conditions. The main concluding remarks of this research are as the following:

The numerical scheme used in the TOASTS model (i.e., CTQS scheme), in cases where advection is the dominant transport process (higher Peclet numbers), has less numerical oscillations and higher stability compared to the CTCS and BTCS numerical schemes.

For a specified level of accuracy, TOASTS can provide larger grid size, while other models based on the central scheme face step limitation that leads to more computational cost.

As shown by other researchers, the inclusion of transient storage and sorption in a classical advection-dispersion equation, in many cases, leads to more accurate simulation results.

The TOASTS model is a comprehensive and practical model, that has the ability of solute transport simulation (reactive and non-reactive), with and without storage, under both steady and unsteady flow regimes, in rivers with irregular cross-sections that from this aspect is unique compared to the other existing models. Thus, it could be suggested as a reliable alternative to current popular models in solute transport studies in natural rivers and streams.

\section{Data availability}

In order to access the data, we kindly ask researchers to contact the corresponding author.

Edited by: Y. Chen

Reviewed by: three anonymous referees

\section{References}

Avanzino, R. J., Zellweger, G., Kennedy, V., Zand, S., and Bencala, K.: Results of a solute transport experiment at Uvas Creek, September 1972, USGS Open-File Report, 84-236, 1984. 
Bencala, K. E.: Simulation of solute transport in a mountain pool-and-riffle stream with a kinetic mass transfer model for sorption, Water Resour. Res., 19, 732-738, doi:10.1029/WR019i003p00732, 1983.

Bencala, K. E.: Interactions of solutes and streambed sediment: 2. A dynamic analysis of coupled hydrologic and chemical processes that determine solute transport, Water Resour. Res., 20, 18041814, doi:10.1029/WR020i012p01804, 1984.

Bencala, K. E., Mcknight, D. M., and Zellweger, G. W.: Characterization of transport in an acidic and metal-rich mountain stream based on a lithium tracer injection and simulations of transient storage, Water Resour. Res., 26, 989-1000, 1990.

Bencala, K. E. and Walters, R. A.: Simulation of Solute Transport in a Mountain Pool-and-Riffle Stream: A Transient Storage Model, Water Resour. Res., 19, 718-724, doi:10.1029/wr019i003p00718, 1983.

Chapra, S. C. and Runkel, R. L.: Modeling impact of storage zones on stream dissolved oxygen, J. Environ. Eng., 125, 415-419, doi:10.1061/(ASCE)0733-9372(1999)125:5(415), 1999.

Chapra, S. C. and Wilcock, R. J.: Transient storage and gas transfer in lowland stream, J. Environ. Eng., 126, 708-712, doi:10.1061/(ASCE)0733-9372(2000)126:8(708), 2000.

Czernuszenko, W., Rowinski, P.-M., and Sukhodolov, A.: Experimental and numerical validation of the dead-zone model for longitudinal dispersion in rivers, J. Hydraul. Res., 36, 269-280, doi:10.1080/00221689809498637, 1998.

Czernuszenko, W. and Rowinski, P.: Properties of the dead-zone model of longitudinal dispersion in rivers, J. Hydraul. Res., 35, 491-504, doi:10.1080/00221689709498407, 1997.

D’Angelo, D., Webster, J., Gregory, S., and Meyer, J.: Transient storage in Appalachian and Cascade mountain streams as related to hydraulic characteristics, J. N. Am. Benthol. Soc., 223-235, doi:10.2307/1467457, 1993.

Day, T. J.: Longitudinal dispersion in natural channels, Water Resour. Res., 11, 909-918, doi:10.1029/WR011i006p00909, 1975.

DeAngelis, D., Loreau, M., Neergaard, D., Mulholland, P., and Marzolf, E. Modelling nutrient-periphyton dynamics in streams: the importance of transient storage zones, Ecol. Modell., 80, 149160, doi:10.1016/0304-3800(94)00066-Q, 1995.

Ensign, S. H. and Doyle, M. W.: In-channel transient storage and associated nutrient retention: Evidence from experimental manipulations, Limnol. Oceanogr., 50, 1740-1751, doi:10.4319/lo.2005.50.6.1740, 2005.

Fernald, A. G., Wigington, P., and Landers, D. H.: Transient storage and hyporheic flow along the Willamette River, Oregon: Field measurements and model estimates, Water Resour. Res., 37, 1681-1694, doi:10.1029/2000WR900338, 2001.

Godfrey, R. G. and Frederick, B. J.: Stream dispersion at selected sites, US Government Printing Office, 1970.

Gooseff, M. N., Hall, R. O., and Tank, J. L.: Relating transient storage to channel complexity in streams of varying land use in Jackson Hole, Wyoming, Water Resour. Res., 43, doi:10.1029/2005WR004626, 2007.

Harvey, J. W. and Wagner, B.: Quantifying hydrologic interactions between streams and their subsurface hyporheic zones, Streams and ground waters, 344 pp., 2000.

Jackman, A., Walters, R., and Kennedy, V.: Transport and concentration controls for Chloride, Strontium, potassium and lead in Uvas Creek, a small cobble-bed stream in Santa Clara County,
California, USA: 2, Mathematical modeling, J. Hydrol., 75, 111141, doi:10.1016/0022-1694(84)90046-5, 1984.

Jackson, T. R., Haggerty, R., and Apte, S. V.: A fluid-mechanics based classification scheme for surface transient storage in riverine environments: quantitatively separating surface from hyporheic transient storage, Hydrol. Earth Syst. Sci., 17, 27472779, doi:10.5194/hess-17-2747-2013, 2013.

Jin, L., Siegel, D. I., Lautz, L. K., and Otz, M. H.: Transient storage and downstream solute transport in nested stream reaches affected by beaver dams, Hydrol. Process., 23, 2438-2449, doi:10.1002/hyp.7359, 2009.

Kazezyılmaz-Alhan, C. M.: Analytical solutions for contaminant transport in streams, J. Hydrol., 348, 524-534, doi:10.1016/j.jhydrol.2007.10.022, 2008.

Keefe, S. H., Barber, L. B., Runkel, R. L., Ryan, J. N., Mcknight, D. M., and Wass, R. D.: Conservative and reactive solute transport in constructed wetlands, Water Resour. Res., 40, doi:10.1029/2003WR002130, 2004.

Laenen, A. and Bencala, K. E.: transient storage assessments of dye-tracer injections in rivers of the Willamette basin, Oregon, JAWRA Journal of the American Water Resources Association, 37, 367-377, doi:10.1111/j.1752-1688.2001.tb00975.x, 2001.

Leonard, B. P.: A stable and accurate convective modelling procedure based on quadratic upstream interpolation, Comput. Method. Appl. M., 19, 59-98, doi:10.1016/00457825(79)90034-3, 1979.

Lin, Y.-C. and Medina Jr., M. A.: Incorporating transient storage in conjunctive stream-aquifer modeling, Adv. Water Resour., 26, 1001-1019, doi:10.1016/S0309-1708(03)00081-2, 2003.

Morrice, J. A., Valett, H., Dahm, C. N., and Campana, M. E.: Alluvial characteristics, groundwater-surface water exchange and hydrological retention in headwater streams, Hydrol. Process., 11, 253-267, 1997.

Neumann, L., Šimunek, J., and Cook, F.: Implementation of quadratic upstream interpolation schemes for solute transport into HYDRUS-1-D, Environ. Modell. Softw., 26, 1298-1308, doi:10.1016/j.envsoft.2011.05.010, 2011.

Nordin, C. F. and Sabol, G. V.: Empirical data on longitudinal dispersion in rivers, WRI, 74-20, 372 pp., 1974.

Nordin, C. F. and Troutman, B. M.: Longitudinal dispersion in rivers: The persistence of skewness in observed data, Water Resour. Res., 16, 123-128, doi:10.1029/WR016i001p00123, 1980.

Putz, G. and Smith, D. W.: Two-dimensional modelling of effluent mixing in the Athabasca River downstream of Weldwood of Canada Ltd., Hinton, Alberta, University of Alberta, 2000.

Ramaswami, A., Milford, J. B., and Small, M. J.: Integrated environmental modeling: pollutant transport, fate, and risk in the environment, J. Wiley, 2005.

Runkel, R. L.: One-dimensional transport with inflow andstorage (otis): a solute transport model for streams and rivers, WaterResources Investigations Report, 1998.

Runkel, R. L., Mcknight, D. M., and Andrews, E. D.: Analysis of transient storage subject to unsteady flow: Diel flow variation in an Antarctic stream, J. N. Am. Benthol. Soc., 17, 143-154, doi:10.2307/1467958, 1998.

Scott, D. T., Gooseff, M. N., Bencala, K. E., and Runkel, R. L.: Automated calibration of a stream solute transport model: implications for interpretation of biogeochemical parameters, J. N. Am. Benthol. Soc., 22, 492-510, doi:10.2307/1468348, 2003. 
Singh, S. K.: Treatment of stagnant zones in riverine advection-dispersion, J. Hydraul. Eng., 129, 470-473, doi:10.1061/(ASCE)0733-9429(2003)129:6(470), 2003.

Szymkiewicz, R.: Numerical modeling in open channel hydraulics, Springer, 2010.

Taylor, G.: The dispersion of matter in turbulent flow through a pipe, P. Roy. Soc. A, 223, 446-468, doi:10.1098/rspa.1954.0130, 1954.

Van Mazijk, A. and Veling, E.: Tracer experiments in the Rhine Basin: evaluation of the skewness of observed concentration distributions, J. Hydrol., 307, 60-78, doi:10.1016/j.jhydrol.2004.09.022, 2005.
Versteeg, H. K. and Malalasekera, W.: An introduction to computational fluid dynamics: the finite volume method, Pearson Education, 2007.

Wagner, B. J. and Harvey, J. W.: Experimental design for estimating parameters of rate-limited mass transfer: Analysis of stream tracer studies, Water Resour. Res., 33, 1731-1741, doi:10.1029/97WR01067, 1997.

Zhang, Y. and Aral, M. M.: Solute transport in open-channel networks in unsteady flow regime, Environ. Fluid Mech., 4, 225 247, doi:10.1023/B:EFMC.0000024237.17777.b1, 2004. 